\title{
PEPTIDE MAPPING OF THE MAJOR COMPONENTS OF IN VITRO SYNTHESIZED BARLEY HORDEIN: EVIDENCE OF STRUCTURAL HOMOLOGY
}

\author{
by
}

\author{
ANTHONY A. HOLDER and JOHN INGVERSEN \\ Department of Physiology, Carlsberg Laboratory, \\ Gamle Carlsberg Vej 10, DK-2500 Copenhagen, Valby
}

Keywords: Endosperm protein, prolamin, fingerprint

\begin{abstract}
Membrane bound polysomes from Bomi barley endosperm were used as a template for in vitro hordein synthesis. The ${ }^{35}$ S)-methionine-labelled hordein was isolated by extraction with $55 \%$ isopropanol and the individual component polypeptides were resolved by SDS-polyacrylamide gel electrophoresis with detection by autoradiography. Eight bands in the molecular weight range 28,000 to 67,000 were excised from the gel. Treatment of the gel slices with chymotrypsin released soluble peptide products from the polypeptides. The resultant peptides were analysed by two dimensional thin layer chromatography and autoradiography of the ( $\left.{ }^{35} S\right)$-methionine-containing peptides. The peptide maps had a number of features in common, suggesting a primary structural homology between the different polypeptides.
\end{abstract}

\section{INTRODUCTION}

Cereal proteins are classified on the basis of their differential solubility; those soluble in diluted alcohol are the prolamins, a group of hydrophobic storage proteins low in lysyl residues and high in glutamyl or glutaminyl and prolyl residues. Hordein, the prolamin from barley endosperm is accumulated in protein bodies (10) and may represent up to $40 \%$ of the protein in a grain (13). Hordein can be resolved 
into a limited number of polypeptides by the criteria of size and charge $(3,10,13)$.

Recently, a cell-free protein synthesizing system has been described for the translation of polysomes derived from barley endosperm (4). Some of the products were identified as hordein on the bases of solubility in $55 \%$ isopropanol and co-migration with native hordein on sodium dodecyl sulphate polyacrylamide gel electrophoresis (SDS-PAGE). The present paper confirms the identification as hordein of products synthesized in vitro in the presence of $\left({ }^{35} \mathrm{~S}\right)$-methionine and describes their comparison by the peptide mapping of chymotryptic digests of eight individual polypeptides from gel slices.

\section{MATERIALS AND METHODS}

2.1. Isolation of endosperm membrane bound polysomes and in vitro protein synthesis

Barley plants (Hordeum vulgare L.) cv. Bomi were grown in a growth chamber and membrane bound polysomes were isolated from endosperm, as described previously (4). The in vitro protein synthesis system using wheat embryo extract in the presence of $\left({ }^{35} \mathrm{~S}\right)$-methionine (specific activity approx. $900 \mathrm{mCi} / \mathrm{mole}$, Radiochemical Center, Amersham, UK) (6) was scaled up to translate $60 \mathrm{~A}_{260}$ units of polysomes. Protein synthesis was terminated by the addition of $1.5 \mathrm{ml} 60 \%$ isopropanol containing $2 \%$ mercaptoethanol, $10 \mathrm{mM}$-methionine, $10 \mathrm{~mm}$-EDTA and $100 \mu \mathrm{g} \cdot \mathrm{ml}^{-1}$ carrier hordein.

\subsection{Resolution of the in vitro synthesized hordein}

Hordein was extracted, S-carboxyamidomethylated and subjected to SDS-PAGE as described previously (6). The gel slab was dried immediately after electrophoresis and the polypeptides were detected by autoradiography using Kodak RP Royal X-Omat film. Eight regions of the gel, containing hordein polypeptides were cut out by reference to the autoradiogram.
The molecular weights of the hordein polypeptides were determined separately on a $10 \%$ acrylamide gel, using bovine serum albumin (M.W. 67,000), ovalbumin (M.W. 45,000), chymotrypsinogen A (M.W. 24,000) and cytochrome c (M.W. 14,000) as molecular weight standards.

\subsection{Digestion with chymotrypsin}

The excised gel slices were washed twice with $90 \%$ acetone, $10 \% 10 \mathrm{~mm}-\mathrm{HCl}$ for two hours to remove SDS and free methionine. The washed gel was then incubated with $1 \mathrm{ml} 0.1 \mathrm{M}-$ ammonium bicarbonate containing $50 \mu \mathrm{g} \cdot \mathrm{ml}^{-1}$ chymotrypsin ( $3 \times$ crystallized and lyophilized, Sigma Chem. Co., St. Louis, U.S.A.) at $37^{\circ} \mathrm{C}$ on a shaking water bath for 16 hours. After removal of the buffer and a second identical treatment with chymotrypsin for 4 hours the pooled supernatants containing the solubilized peptides were frozen and dried in vacuo.

\subsection{Preparation of chymotryptic peptides from total hordein}

Total hordein was extracted from barley meal as described by CAMERoN-MiLls et al. (6) and S-carboxyamidomethylated essentially by the procedure of HIRS (9). The hordein was digested with $2 \%(\mathrm{w} / \mathrm{w})$ chymotrypsin in $0.1 \mathrm{M}$ ammonium bicarbonate at $34^{\circ} \mathrm{C}$ for 6 hours. The reaction was terminated by the addition of glacial acetic acid followed by freeze drying.

\subsection{Amino acid analysis of hordein}

Samples of performic acid oxidized and unmodified hordein were hydrolyzed for $24,48,72$ and 96 hours at $110^{\circ} \mathrm{C}$ using $6 \mathrm{M}-\mathrm{HCl}$ containing $0.1 \%$ phenol. Analyses were performed on a Durrum D500 amino acid analyser.

\subsection{Chymotryptic peptide mapping}

The chymotryptic peptides were analyzed by two dimensional chromatography on $10 \mathrm{~cm} x$

Abbreviations: SDS-PAGE = sodium dodecyl sulphate polyacrylamide gel electrophoresis; TCA = trichloroacetic acid; $\mathrm{TLC}=$ thin layer chromatography. 
$10 \mathrm{~cm}$ silica gel $\mathrm{G}$ coated TLC plates (Merck). The samples were applied in $0.1 \mathrm{M}-\mathrm{NH}_{3}$. The plates were developed in the first dimension with isopropanol-25\% ammonia (65:35, v/v) and, after air drying, at right angles in the second dimension with butanol-methanolacetic acid-water-pyridine (45:30:6:24:20, v/v). After drying the plates, the radioactive peptides were detected by autoradiography using Kodak RP Royal X-Omat film. The plates were stained by dipping in cadmium-ninhydrin reagent (7) to reveal ninhydrin detectable peptides.

\section{RESULTS}

\subsection{Characterization of the in vitro products as hordein}

A comparison of the $55 \%$ isopropanol-soluble, $\left.{ }^{35} \mathrm{~S}\right)$-methionine-labelled, in vitro polysome products with ${ }^{14} \mathrm{C}$-labelled, in vivo-synthesized hordein by SDS-PAGE is shown in Figure 1 (tracks 1 and 2, respectively). The pattern of isopropanol-soluble in vitro products closely resembles the distribution of polypeptides in native hordein, so that the apparent molecular weights of the respective polypeptides are identical. The low molecular weight products in Track 1 may represent products of premature chain termination (14) and were not analyzed further. The nomenclature for the hordein polypeptide bands is based on that suggested by $K \emptyset \mathrm{IE}$ et al. (11) who subdivided the isopropanol soluble polypeptides into 3 groups $\mathrm{A}, \mathrm{B}$ and $\mathrm{C}$ by the criterion of their mobility in SDS-PAGE. The low molecular weight A-group polypepetides are not considered to be hordein because they are not present in protein bodies (10).

\subsection{Chymotryptic peptide mapping of total native hordein and the in vitro products}

Preliminary experiments showed that native hordein was not fully solubilized by prolonged digestion with trypsin, a result consistent with the low content of lysine and arginine (see Table I). Chymotrypsin, however, was effective in solubilizing hordein. When the resultant pep-

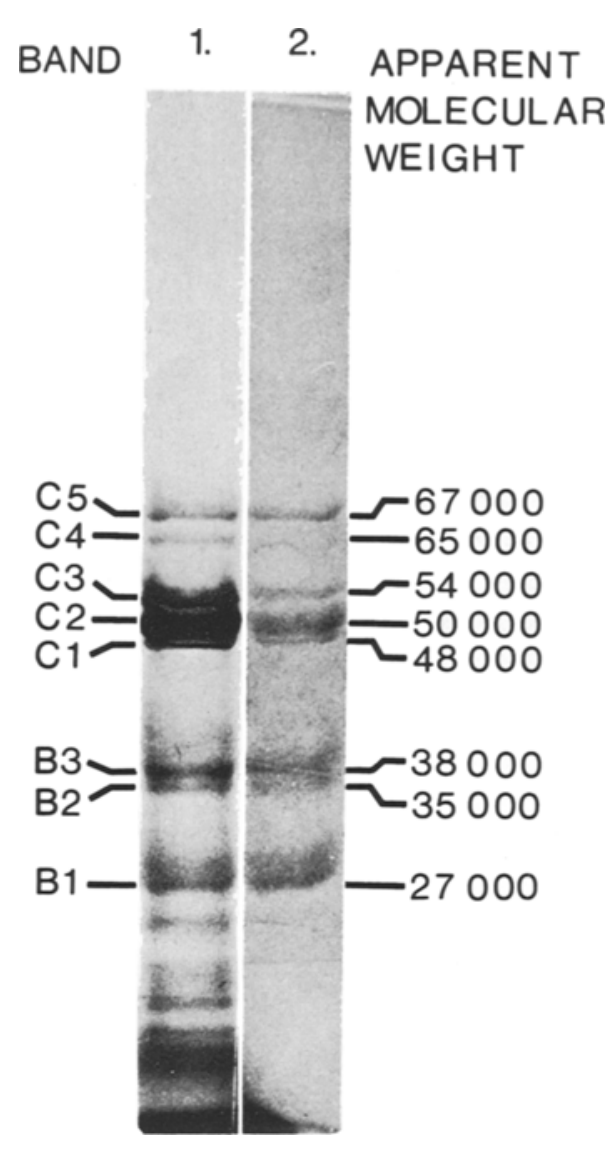

Figure 1. A comparison by SDS-PAGE and autoradiography of the $\left({ }^{3 s} \mathrm{~S}\right)$-methionine-labelled, isopropanolsoluble in vitro products from endosperm polysome directed protein synthesis (Track 1) with native hordein labelled in vivo with $\left({ }^{14} \mathrm{C}\right)$-amino acids (Track 2). The regions excised from the gel for chymotryptic peptide analysis are indicated on the left. The apparent molecular weights were determined separately on a $10 \%$ acrylamide gel.

tides from S-carboxyamidomethylated total hordein were subjected to two dimensional chromatography on silica gel TLC plates a characteristic pattern of peptides was obtained. Figure 2 shows a representation of a typical "fingerprint" of native hordein after staining with ninhydrin. A very complex pattern of peptide spots was obtained with many incompletely resolved peptides. 
Table I

Amino acid composition of total hordein extracted from mature barley meal.

Mole \%

Amino acid (Residues/100 Residues)

\begin{tabular}{lr}
\hline Methionine $^{\text {a) }}$ & 1.11 \\
Cysteine $^{\text {b) }}$ & 2.29 \\
Aspartic acid $^{\text {Threonine }}{ }^{\text {c) }}$ & 1.72 \\
Threrine $^{c)}$ & 2.03 \\
Glutamic acid & 4.14 \\
Proline & 34.85 \\
Glycine & 21.50 \\
Alanine & 2.52 \\
Valine & 2.57 \\
Isoleucine & 4.83 \\
Leucine & 3.90 \\
Tyrosine & 7.20 \\
Phenylalanine & 2.25 \\
Histidine & 5.57 \\
Lysine & 1.32 \\
Arginine & 0.70 \\
\end{tabular}

a) Determined as methionine sulphone after performic acid oxidation.

b) Determined as cysteic acid after performic acid oxidation.

c) Extrapolated to zero time.

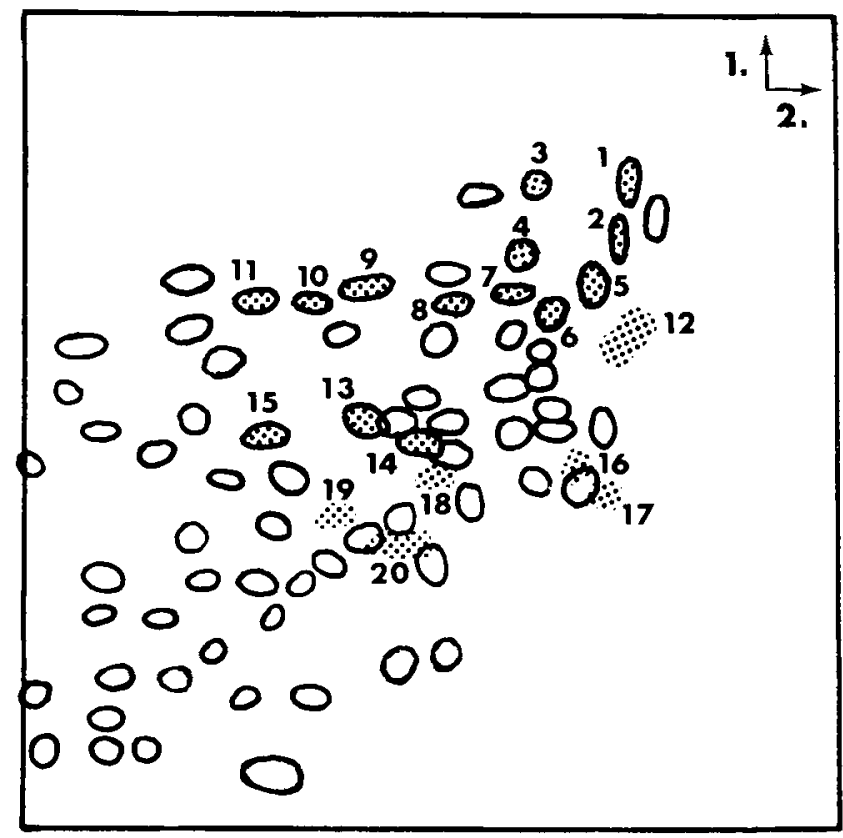

Chymotrypsin treatment of the individual polypeptides in the gel released soluble peptides into the buffer. A total of $0.08 \mu \mathrm{Ci}\left({ }^{35} \mathrm{~S}\right)$ methionine-containing peptides was released from the gel, corresponding to $1.1 \%$ of the original TCA-precipitable radioactive material.

When the chymotryptic peptides derived from the in vitro synthesized hordein products were subjected to two dimensional TLC only the products containing $\left({ }^{35} \mathrm{~S}\right)$-methionine were detected by autoradiography. At least 20 radioactive spots could be seen, as depicted by the cross-hatched areas in Figure 2. Many of the radioactive peptides corresponded in position with peptides derived from total native hordein. The individual autoradiograms from the eight excised areas of the polyacrylamide gel are displayed in Figure 3. The origin is at the bottom left-hand corner of each chromatogram, and only in the case of $\mathrm{C} 3$ was there any significant amount of radioactive material at the origin. Clearly not every spot was present on all the peptide maps and some spots were present in different relative amounts. In a separate experiment it was found that free methionine had mobilities in the two chromatographic systems which were identical with peptide 5 . Therefore, the identity of peptide 5 with free methionine cannot be excluded, but the limited distribution of peptide 5 and the presence of a peptide in this position from total hordein would suggest that peptide 5 is a peptide and not free methionine.

Figure 2. Two dimensional chromatographic separation of chymotryptic peptides from hordein on silica gel TLC plates. The sample was applied to the origin at the bottom left-hand corner. The plate was developed in the first dimension (1) with isopropanol-25\% ammonia $(65: 35, \mathrm{v} / \mathrm{v})$ and then at right angles in the second dimension (2) with butanol-methanol-acetic acid-water-pyridine (45:30:6:24:20, v/v). The closed lines represent ninhydrin-detected peptides from $\mathbf{S}$ carboxyamidomethylated total hordein. The numbered, cross-hatched areas indicate the position of $\left({ }^{35} \mathrm{~S}\right)$-methionine-labelled peptides derived from polypeptides synthesized in vitro and detected by autoradiography. 
The distribution of the radioactive peptides amongst the chymotryptic products from the individual polypeptides is shown in Table II. It can be seen that the peptides numbered $1,6,11$, 13,14 and 15 were present on all the fingerprints. Other peptides had a restricted distribution, for example, peptide 12 was only observed for B1, B2, B 3 and C4, whereas peptides $5,16,17$ and 20 were present only in $C$ polypeptides. Two peptides, 7 and 19 were derived from only one polypeptide respectively, others including peptides $2,3,4,8,10$ and 18 were observed from two or three polypeptides.

\section{DISCUSSION}

Some of the products from the in vitro protein synthesis directed by barley endosperm membrane bound polysomes have previously been shown to be hordein on the bases of solubility in $55 \%$ isopropanol and mobility on SDS-polyacrylamide gels (4). In the present study SDS-PAGE and autoradiography of the $\left({ }^{35} \mathrm{~S}\right)$-methionine-labelled, in vitro synthesized polypeptides gave a better resolution of the polysome products than that obtained previously. It is clear that the membrane bound polysomes from Bomi barley endosperm coded for at least eight of the in vivo synthesized hordein polypeptides which can be detected either by autoradiography of the native $\left({ }^{14} \mathrm{C}\right)$ labelled hordein (Figure 1) or by coomassie blue staining of native hordein after separation by SDS-PAGE (13). The co-chromatography of methionine-containing chymotryptic peptides from the in vitro product with chymotryptic peptides from total hordein, (Figure 2) is additional evidence that the products investigated were hordein.

The heterogeneity of storage proteins from cereal endosperm (prolamins) has been investigated by a number of electrophoretic and chromatographic techniques to detect size and charge differences; and, for the prolamin from wheat (gliadin), by peptide mapping and N-terminal sequence analysis of some purified peptides. Zein, the prolamin of maize can be resolved into 4 polypeptides by SDS-PAGE, but up to 15 components are displayed by isoelectric focusing (12). Peptide mapping (1) and $\mathrm{N}$-terminal amino acid sequence (2) studies have shown that some of the gliadin polypeptides of hexaploid wheat are homologous to one another but the situation is complicated by the presence of many polymorphisms. In barley, size heterogeneity of hordein polypeptides can be detected by SDS-PAGE (Figure 1). Polypeptide bands $\mathrm{C} 1, \mathrm{C} 2$ and $\mathrm{C} 3$ appear to be resolved into 4 or 5 polypeptides upon two dimensional electrophoresis (13).

According to ELDER et al. (8) proteins can be digested with protease after separation by SDSPAGE without prior elution of the polypeptide from the gel to allow characterization of the solubilized peptide products. This approach has been used to compare the methionine-containing peptides derived by chymotryptic digestion of hordein polypeptides in 8 apparent molecular weight classes. The total recovery of methionine-labelled material from the gel amounting to $1.1 \%$ of the total TCA-precipitable product requires comment. As only approximately $10 \%$ of the TCA-precipitable material is soluble in $55 \%$ isopropanol (4) and as this fraction further contains probably substantial amounts of low molecular weight material and free methionine we consider the obtained peptide maps representative for hordein.

The number of methionine peptides detected by autoradiography was higher than the calculated average content of this amino acid in total native hordein ( 1.11 mole $\%$, equivalent to 0.9 residues per 10,000 molecular weight) (Table I). Approximately $50 \%$ of the incorporated radioactivity was due to reinitiation in the protein synthesis system (J. INGVERSEN, unpublished observation) so that $\left.{ }^{(35} S\right)$ methionine should be incorporated throughout the polypeptide chain, although the specific activity of residues near the C-terminus would be higher. The initiation methionine is partially cleaved from the nascent chains, and therefore expected to be present only on some of the polypeptides in each weight class (5). The rather broad specificity of chymotrypsin could have resulted in any single methionine appearing in a number of degenerate peptides.

On the basis of the results which have been presented (Figure 3 and Table II) the in vitro synthesized hordein polypeptides are very 


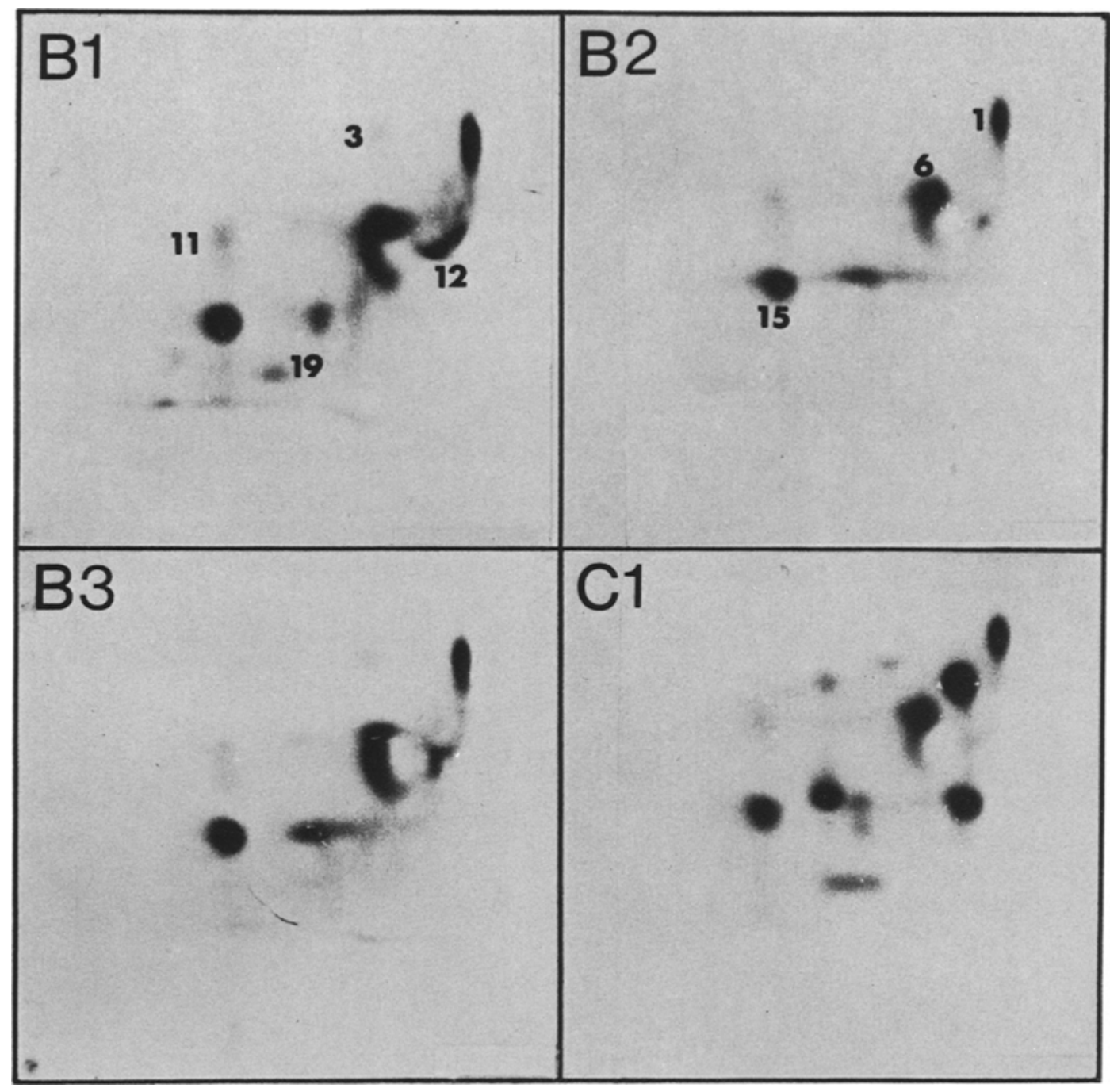

Figure 3. Autoradiograms of $\left.{ }^{35} \mathrm{~S}\right)$-methionine-containing peptides which were released by the treatment with chymotrypsin of acrylamide gel slices containing in vitro synthesized hordein polypeptides. The chromatographic conditions were identical to those described for Figure 2. The SDS-PAGE separation of hordein polypeptides from which the gel slices were taken is that shown in Figure 1. The peptides are numbered as in Figure 2.

similar in that they have 6 methionine-containing peptides in common. They can be further divided into two broad groups, B1, B2, B3 and $\mathrm{C} 4$ and $\mathrm{C} 1, \mathrm{C} 2, \mathrm{C} 3$ and $\mathrm{C} 5$ on the basis of further similarities in the peptide pattern. The polypeptide $\mathrm{C} 4$ is, in fact, a component not always prominent amongst the polysome products or in native hordein, which together with the present results strongly suggest that it is a polymer of a B-type hordein (possibly B2) or due to incomplete saturation of a B-type hordein with SDS during preparation for electrophoresis. The extra radioactive peptides derived from the $\mathrm{C}$-band polypeptides, in ad- 


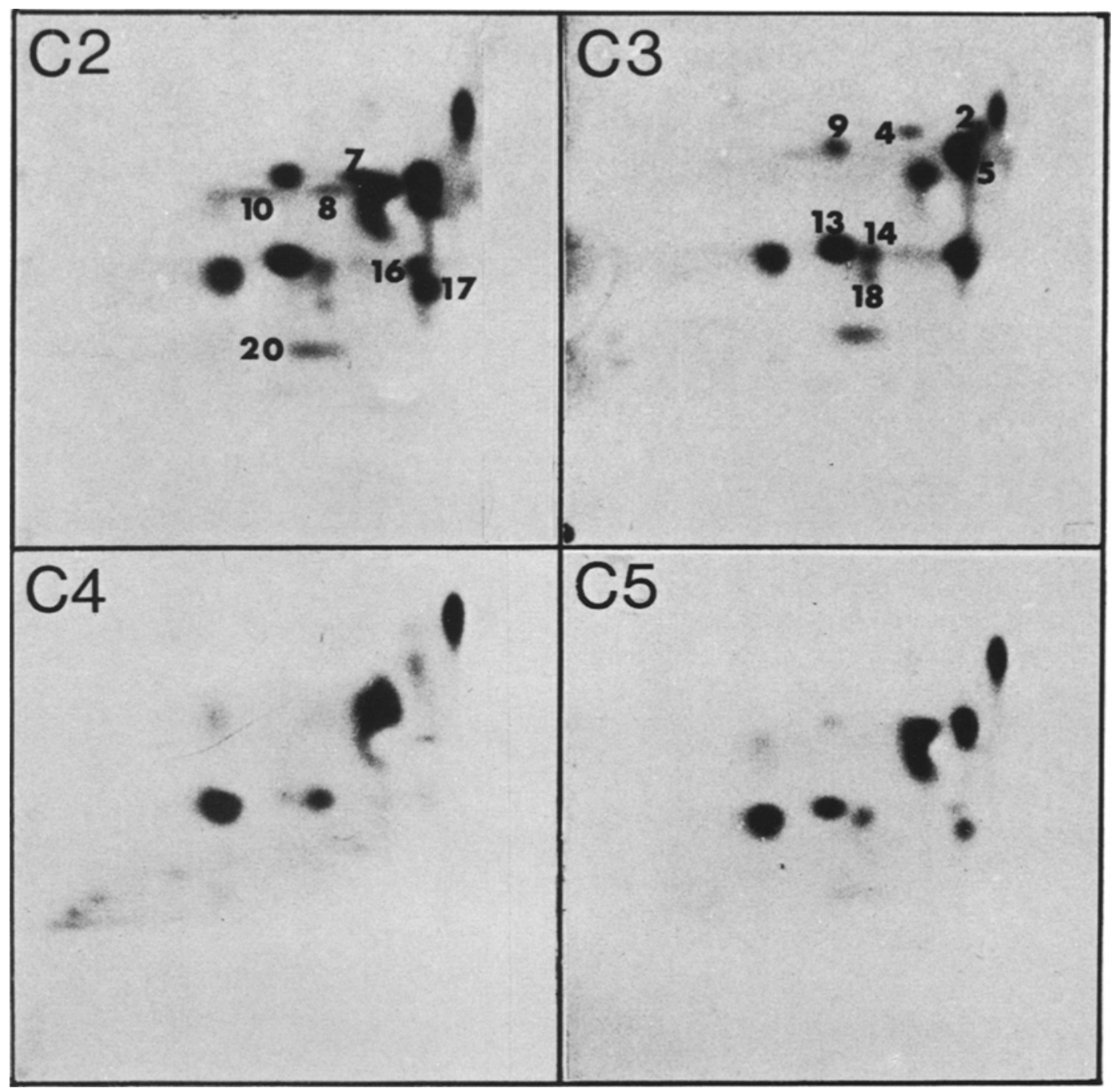

Table II

Distribution of $\left({ }^{35} \mathrm{~S}\right)$-methionine-containing peptides on the fingerprints of individual hordein polypeptides after digestion with chymotrypsin. The nomenclature for polypeptides refers to Figure 1 and that for peptides to Figure 2.

Polypeptide Peptide number

\begin{tabular}{|c|c|c|c|c|c|c|c|c|c|c|c|c|c|c|c|c|c|c|c|c|}
\hline band & 1 & 2 & 3 & 4 & 5 & 6 & 7 & 8 & 9 & 10 & 11 & 12 & 13 & 14 & 15 & 16 & 17 & 18 & 19 & 20 \\
\hline B I & +++ & + & + & - & - & -+++ & - & + & - & - & + & +++ & + & ++ & +++ & - & - & - & + & - \\
\hline $\mathrm{B} 2$ & +++ & - & - & - & - & -++ & - & - & - & - & + & + & ++ & + & +++ & - & - & - & - & - \\
\hline B3 & +++ & - & + & - & - & -++ & - & - & + & - & + & ++ & +++ & + & +++ & - & - & - & - & - \\
\hline Cl & +++ & - & - & + & $+t+$ & $+t+$ & - & - & + & + & + & - & $+t+$ & ++ & +++ & +++ & ++ & + & - & ++ \\
\hline $\mathrm{C} 2$ & +++ & - & - & - & +++ & $+t+$ & ++ & + & ++ & + & + & - & +++ & + & +++ & ++ & +++ & + & - & + \\
\hline C3 & +++ & ++ & - & + & +++ & ++ & - & - & + &.+ & + & - & $++t$ & + & +++ & ++ & ++ & + & - & + \\
\hline C4 & +++ & - & - & - & + & +++ & - & - & - & - & + & + & + & ++ & +++ & + & - & - & - & - \\
\hline C5 & +++ & - & - & - & $+t+$ & $+t+$ & - & - & + & - & + & - & ++ & + & +++ & + & + & - & - & + \\
\hline
\end{tabular}

$+++=$ strong autoradiographic image

$++=$ moderate autoradiographic image

$+=$ weak autoradiographic image

- = no autoradiographic image 
dition to those in common with the B-bands, are consistent with their higher molecular weight.

The homology between the hordein polypeptides suggests a common origin of the genetic material coding for them. Two possibilities can be considered: either each polypeptide is coded by an individual structural gene resulting from gene duplication and mutation, or the different molecular weight species represent the products of one or a few DNA sequences for which a number of chain termination or initiation points exist.

\section{ACKNOWLEDGEMENTS}

We would like to thank Bodil CORNELIUSSEN for performing the amino acid analyses. A. HOLDER gratefully acknowledges the receipt of a Royal Society European Science Exchange Programme Fellowship. This work was supported by a grant from the USPHS, National Institutes of Health (GM-22051) to professor D. VON WETTSTEIN.

\section{REFERENCES}

1. Bietz, J, A., F. R. Huebner \& J. A. Rothfus: Chromatographic comparisons of peptic digests of individual gliadin proteins. Cereal Chem. 47, 393-404 (1970)

2. Bietz, J. A., F. R. Huebner, J. E. SANderson \& J. S. WALL: Wheat gliadin homology revealed through $\mathrm{N}$-terminal amino acid sequence analysis. Cereal Chem. 54, 1070-1083(1977)

3. BRANDT, A.: Endosperm protein formation during kernel development of wild type and a high lysine barley mutant. Cereal Chem. 53, 890-901 (1976)

4. BRANDT, A. \& J. INGVERSEN: In vitro synthesis of barley endosperm proteins on wild type \& mutant templates. Carlsberg Res. Commun. 41, 311-320 (1976)
5. Burstein, Y., F. Kantor \& I. SChechter: Partial amino acid sequence of the precursor of an immunoglobulin light chain containing $\mathrm{NH}_{2}$-terminal pyroglutamic acid. Proc. Nat. Acad. Sci. USA 73, 2604-2608 (1976)

6. Cameron-Mills, V., J. Ingversen and A. BRANDT: Transfer of in vitro synthesized barley endosperm proteins into the lumen of the endoplasmic reticulum. Carlsberg Res. Commun, 43, 91-102 (1978)

7. Dawson, R. M. C., D. C. Elliot, W. H. Elliot \& K. M. JONES: In: Data for biochemical research, Oxford University Press. London pp. 525-534 (1969)

8. Elder, J. H., F. C. Jensen, M. L. Bryant \& R. A. LERNer: Polymorphism of the major envelope glycoprotein ( $g$ p 70) of murine C-type viruses: virion associated and differentiation antigens encoded by a multi-gene family. Nature, 267, 2328 (1977)

9. HiRs, C. H. W.: Reduction and S-carboxymethylation of proteins. Methods Enzymol. 11, 199-203 (1967)

10. InGVersen, J.: Structure and composition of protein bodies from wild type and high lysine barley endosperm. Hereditas 81, 69-76 (1975)

11. Køie, B., J. Ingversen, A. J. Andersen, H. Doll \& B. O. EgGuM: Composition and nutritional quality of barley protein. In: Evaluation of seed protein alterations by mutation breeding, Int. Atomic Energy Agency, Panel Proc. Ser. Sti/Pub/ 426. Vienna, pp. 55-61 (1976)

12. Righetti, P. G., E. Gianazza, A. Viotti \& C. SOAvE: Heterogeneity of storage proteins in maize. Planta 136, 115-123 (1977)

13. Shewry, P. R., H. M. Pratt, M. J. Charlton \& B. J. MIFLIN: Two-dimensional separation of the prolamins of normal and high lysine barley (Hordeum vulgare L.). J. Exp. Bot. 28, 597-606 (1977)

14. T. P. H. TSE \& J. M. TAYLOR: Translation of albumin messenger RNA in a cell-free proteinsynthesizing system derived from wheat germ. J. Biol. Chem. 252, 1272-1278 (1977) 